\title{
THE USE OF FLASHCARD GAMES IN THE APPLICATION OF COGNITIVE BEHAVIOR THERAPY (CBT) IN SCHIZOPHRENIC PATIENTS WITH RISK OF VIOLENT BEHAVIOR
}

\author{
Sri Maryatun ${ }^{1}$,Zulian Effendi ${ }^{2}$, Sayang Ajeng Mardhiyah ${ }^{3}$ \\ 1,2 Nursing Science Study Program, Sriwijaya University, Street Palembang Prabumulih KM 32, \\ Indralaya District Ogan Ilir, South Sumatera 30662, Indonesia \\ ${ }^{3}$ Psychology Study Program, Sriwijaya University Street Palembang Prabumulih KM 32, Indralaya \\ District Ogan Ilir, South Sumatera 30662, Indonesia
}

\begin{abstract}
The increase in maladaptive behavior of schizophrenic patients in recent times, such as violent behavior, hitting people, breaking things until they commit a murder, has been troubling for the community. This situation is a serious concern for all parties, especially health workers, to provide comprehensive and effective mental nursing care management in reducing the symptoms of maladaptive behavior. Group therapy based on Cognitive Behavior Therapy (CBT) with Flashcard media is one of the development and innovation models of psychotherapy that can be useful in overcoming violent behavior in schizophrenia patients. This study was aimed to determine the effectiveness of CBT with flashcards on changes in violent behavior in schizophrenic patients. The research design was used a quasi-experimental pre-posttest with a control group. A sample of 50 people includes 25 people in the intervention group and 25people in the control group. The results were showed that the reduction in signs and symptoms of schizophrenic patients was greater in the intervention group than in the control group, with a value of $p=0,000$. The CBT therapy with flashcards was effective $66.6 \%$ in reducing violent behavior. CBT therapy with flashcards is recommended to be applied as effective, efficient, and easy therapy for health professionals and families to reduce violent behavior.
\end{abstract}

Keywords: Cognitive Behavior Therapy (CBT), Flashcard, Violent Behavior

\begin{abstract}
ABSTRAK
Peningkatan perilaku maladaptive dari pasien schizophrenia pada akhir -akhir ini seperti perilaku kekerasan,memukul orang, merusak barang sampai melakukan pembunuhan telah meresahkan masyarakat. Keadaantersebut menjadi perhatian yang serius bagi semua pihak khususnya tenaga kesehatan agar mampumemberikan penatalaksanaan asuhan keperawatan jiwa yang komprehensif dan efektif dalam menurunkangejala perilaku maladaptive tersebut.Terapi kelompok berbasis Cognitive Behaviour therapy (CBT) denganmedia Flashcard game merupakan salah satu model pengembangan dan inovasi dari psikoterapi yang dapatbermanfaat lebih cepat dalam mengatasi masalah perilaku kekerasan pada pasien schizophrenia. Penelitian ini bertujuan untuk mengetahui efektivitas CBT dengan flashcard terhadap perubahan perilakukekerasan pada pasien schizoprenia. Desain penelitian quasi experimental pre-posttest with control group.Sampel berjumlah 50 orang meliputi 25 orang dalam kelompok intervensi dan 25 orang dalam kelompok kontrol. Hasil penelitian menunjukkan penurunan tanda gejala dan perilaku pasien schizoprenia lebih besar padakelompok intervensi dibandingkan kelompok kontrol dengan nilai $\mathrm{p}$ value $=0,000$.Terapi CBT dengan flashcard efektif sebesar 66,6\% dalam menurunkan perilaku kekerasan. Terapi CBT dengan flashcard direkomendasikan sebagaiterapi yang efektif,efisien dan mudah dilakukan oleh tenaga kesehatan serta keluarga untuk mencegahterjadinya perilaku kekerasan
\end{abstract}

Kata kunci: Cognitive Behavior Therapy (CBT), Flashcard, Perilaku Kekerasan

${ }^{1}$ Correspondence Address: Sri maryatun, Nursing Science Study Program, Sriwijaya University, Street Palembang Prabumulih KM 32 , Indralaya District Ogan Ilir, South Sumatera 30662, Indonesia, E-mail: tunce79@yahoo.com 


\section{Introduction}

The prevalence of mental disorders has more than 450 million people each year. ${ }^{1}$ Mental illness is found in all countries; it occurs at all stages of life, including adults, and has increased cases of mental disorders. Data of Riskesdas 2013 indicates the prevalence of mental disorders reached $5,6 \%$ of the population or 1,7 per mile and had gained to $14,5 \%$ or 8 per mil households. That means in every 1.000 households, there are 8 households with People with Mental Disorder (PMD). ${ }^{2}$ According to medical record data at Ernaldi Bahar Hospital in South Sumatera Province, the case number of violent behavior patients in 2017 is 3.200 people. In 2018, the number of hospitalized patients in Ernaldi Bahar hospital South Sumatera increased by 4.534 cases with a recurrence rate of $13 \%{ }^{3}$

According to the Alliance on Mental Illness of America, a Mental disorder is an individual health condition characterized by disturbance of thinking, emotion, mood, and inability to interact with others and carry out daily activities. ${ }^{4}$ Statistic data from the Indonesian Ministry of Health (Kemenkes) 2018 shows that the most severe mental disorder clients are schizophrenia; 70\% and $90 \%$ of clients treated at mental hospitals in Indonesia are schizophrenia. Schizophrenia can be caused by clients' previous stressful experiences that threaten a weak ego, often think negatively, and the threat is perceived to interfere with self-concept or self-integrity and result in low selfesteem. ${ }^{6}$ In stressful situations, a person with chronic psychological burden is without family support and those around them. They try to free the burden of their thoughts and feelings by reacting with irritation, anger, and showing uncontrolled violent behavior. ${ }^{7}$

Schizophrenia is also strongly linked to suicide incidence. More than $90 \%$ of one million suicide cases each year in Indonesia are due to mental disorders. ${ }^{8}$ The impact of mental disorders is the increased burden or cost of medical care because clients can no longer be productive at work due to their mental disabilities. In the early stage of mental

disables, their families will seek stimulant help with a large expenditure budget. ${ }^{9}$ Patients with mental disorders are more than $80 \%$ experienced recurrences and showed progressive episodes of their function such as cognitive, social, work, and psychosocial functions. ${ }^{10}$ The prevalence will continue to increase if there is no prevention of schizophrenia and efforts to treat and care for clients properly.

Cognitive Behavior Therapy (CBT) becomes very effective in overcoming the disruption of angry expression and violent behavior because, in this group therapy, the members learn the strategies and techniques to control anger, express it in a healthy way, change hostility and prevent aggression and violence behavior. ${ }^{11}$ Another research was done by Sasmita showed that cognitive ability in low self-esteem schizophrenic patients has significantly increased after CBT by 17,14 with 
p-value $\leq$ a 0,05 compared to the control group 7,72. ${ }^{12}$ Although Cognitive Behavior Therapy (CBT) can overcome the problems of violent behavior and self-esteem, there are still having obstacles in its implementation.

A study that was done by Maryatun had found that the average value of each respondent was decreased violent behavior score from 20,22 to 31,1 after the clients were given Cognitive Behaviors Therapy (CBT) in 2 weeks session ${ }^{13}$ Cognitive Behavior Therapy consists of 5 sessions; it takes a long time for the patients to identify and mention their negative thoughts and needs guidance to find positive thoughts and write them in the CBT assignment book so that these conditions affect the activity process in following sessions.

The next problem in the implementation process of CBT group therapy is client tends to get bored, unfocused, need to be intensively oriented, and need a group leader with a solid team to make the CBT group conducive and effective. ${ }^{14}$ Following up on these issues, researchers felt the need to create creative, interactive, innovative, and simple media by using flashcards in the application of Cognitive Behavior Therapy (CBT).

\section{Methods}

This study used Quasi Experimental Pre-Post Test with Control group design with Cognitive Behavioral Therapy (CBT) intervention with flashcard media. This study was aimed to determine reduced sign and symptoms and CBT ability on risk of violent behavior patients before and after received CBT therapy with flashcard. The sample in this study were 50 people with 25 respondents included in the intervention group and 25 people in control group. The sampling technique used in this study was purposive sampling where the sampling was determined by inclusion criteria: 18-55 years old patients with a diagnosis of schizophrenia, reason for hospitalized due violent behavior, not in ragging stage, cooperative and willing to be a respondent.

The data were analyzed with univariate and bivariate analysis. Univariate analyses were carried out numeric data to determine the frequency distribution of respondent characteristics based on age and responses to symptoms such as cognitive, affective, behavior, physiological and social response using central tendency. The categorical data such as sex, level of knowledge, history of mental disorder and previous hospitalization experience were analyzed using chi square test. Bivariate analysis was carried out to determine the changes on the risk of violent behavior sign and symptom responses such as cognitive, affective, behavior, physiological and social responses before and after received the CBT using flashcard media on both groups using dependent TTest. Independent T-test were used to analyzed the changes of risk of violent behavior signs and symptoms such as cognitive, affective, behavior, physiological and social responses after given CBT with flashcards on both intervention and control groups. This research had previously passed the ethical test and was declared feasible to conduct research with the 
issuance of an ethics letter from the faculty of medicine with number 527/Kepkrrsmhfkunsri/2020.

\section{Results}

Table 1. Equality Analysis of Patients Age in The Intervention and Control Group at Ernaldi Bahar Hospital Palembang $(n=50)$

\begin{tabular}{cccccccc}
\hline Variable & Group & n & Mean & Median & SD & Min-max & P-value \\
\hline Ages & Intervention & 25 & 30,43 & 29,0 & 8,137 & $18-50$ & \\
& Control & 25 & 30,09 & 30,0 & 7,182 & $18-47$ & 0,565 \\
& Total & 50 & 30,26 & 29,5 & 7,659 & $18-50$ & \\
\hline
\end{tabular}

Table 1 showed that out of 50 respondents who participated in this study, the average age of the patients was 30,26 years, with the youngest being 18 years, and the oldest was 50 years. Based on the age equality statistic test of respondents, table 1 showed there was no significant mean age difference between the group who received CBT with flashcard media and the group who didn't receive CBT with a p-value $0,565 \geq \mathrm{a} 0,05$.

Table 2. Equality Analysis of Patients Sex, Occupation, Level of Education, Marital Status, Mental Disorder History, Frequency of Hospitalization in The Intervention and Control Group at Ernaldi Bahar Hospital Palembang $(n=50)$

\begin{tabular}{|c|c|c|c|c|c|c|c|}
\hline \multirow[t]{2}{*}{ Characteristics } & \multicolumn{2}{|c|}{$\begin{array}{l}\text { Intervention } \\
\text { group }(n=25)\end{array}$} & \multicolumn{2}{|c|}{$\begin{array}{c}\text { Control group } \\
(n=25)\end{array}$} & \multicolumn{2}{|c|}{$\begin{array}{c}\text { Total } \\
(\mathbf{n}=\mathbf{5 0})\end{array}$} & \multirow[t]{2}{*}{ P-value } \\
\hline & $\mathbf{n}$ & $100 \%$ & $\mathbf{n}$ & $100 \%$ & $\mathbf{n}$ & $100 \%$ & \\
\hline \multicolumn{8}{|l|}{ 1.Sex } \\
\hline a. Male & 16 & 64,0 & 20 & 80,0 & 36 & 72,0 & 0,487 \\
\hline b. Female & 9 & 36,0 & 5 & 20,0 & 14 & 28,0 & \\
\hline \multicolumn{8}{|l|}{ 2.Occupation } \\
\hline a. Student / Colleger & 1 & 4,0 & 2 & 8,0 & 3 & 6,0 & 0,502 \\
\hline b. Civil Servants & 1 & 4,0 & 0 & 0 & 1 & 2,0 & \\
\hline c. Entrepreneur & 12 & 48,0 & 10 & 40,0 & 22 & 44,0 & \\
\hline d. Unemoloyed & 11 & 44,0 & 13 & 52,0 & 24 & 48,0 & \\
\hline \multicolumn{8}{|l|}{ 3. Marital status } \\
\hline a. Married & 9 & 36,0 & 8 & 32,0 & 17 & 34,0 & 0,588 \\
\hline b. Divorced & 5 & 20,0 & 3 & 12,0 & 8 & 16,0 & \\
\hline c. Single & 11 & 44,0 & 14 & 56,0 & 25 & 50,0 & \\
\hline \multicolumn{8}{|l|}{ 4. Level of Education } \\
\hline a. Elementary School & 8 & 32,0 & 9 & 36,0 & 17 & 34,0 & 0,521 \\
\hline b. Junior High School & 3 & 12,0 & 6 & 24,0 & 9 & 18,0 & \\
\hline c.Senior High School & 13 & 52,0 & 9 & 36,0 & 22 & 44,0 & \\
\hline d. College & 1 & 4,0 & 1 & 4,0 & 2 & 4,0 & \\
\hline \multicolumn{8}{|l|}{$\begin{array}{l}\text { 5.Mental disorder } \\
\text { history }\end{array}$} \\
\hline a. Yes & 9 & 36,0 & 12 & 48,0 & 21 & 42,0 & 0,277 \\
\hline b. No & 16 & 64,0 & 13 & 52,0 & 29 & 58,0 & \\
\hline \multicolumn{8}{|l|}{ 6. Frequency treated } \\
\hline a. First & 9 & 36,0 & 12 & 48,0 & 21 & 42,0 & 0,401 \\
\hline b. 2 times/ more & 16 & 64,0 & 13 & 52,0 & 29 & 58,0 & \\
\hline
\end{tabular}


Table 2 showed that most respondents were $72 \%$ of male $(n=36)$, mostly unemployed were $48 \%(n=24), 50 \%$ were single, educational background were at senior high school $44 \%(n=22)$, $58 \%(\mathrm{n}=29)$ had a mental disorder history and respondents who have done frequency treated more than 2 times were $58 \%(\mathrm{n}=29)$. Based on the table, the result of statistical equality test of the characteristics such as sex, occupation, marital status, level of education, mental disorder history, and frequency of hospitalization, there was no significant difference between the group who received CBT with flashcard media and the group who didn't receive CBT. This indicates that both groups have homogeneous variants

Table 3.Equality Analysis Risk of Violent Behavior Sign and Symptom in the Intervention and Control Group at Ernaldi Bahar Hospital Palembang (n=50)

\begin{tabular}{cllccc}
\hline Symptoms & Group & n & Mean & SD & Min-max \\
\hline \multirow{3}{*}{ Cognitive } & 1. Intervention & 25 & 15,03 & 3,253 & $8-20$ \\
& 2. Control & 25 & 15,6 & 2,711 & $9-19$ \\
& & 50 & 15,31 & & $8-20$ \\
Affective & 1. Intervention & 25 & 18,03 & 3,642 & $6-19$ \\
& 2. Control & 25 & 18,67 & 3,123 & $10-20$ \\
& & 50 & 18,35 & & $6-20$ \\
Behavior & 1. Intervention & 25 & 14,53 & 3,275 & $7-20$ \\
& 2. Control & 25 & 15,67 & 2,539 & $8-20$ \\
& & 50 & 15,16 & & $7-20$ \\
Social & 1. Intervention & 25 & 16,27 & 3,132 & $11-19$ \\
& 2. Control & 25 & 16,67 & 3,827 & $10-20$ \\
& & 50 & 16,57 & & $11-20$ \\
Physiological & 1. Intervention & 25 & 8,27 & 1,035 & $7-10$ \\
& 2. Control & 25 & 8,6 & 1,197 & $7-10$ \\
& & 50 & 8,44 & & $7-$ Oct \\
& 1. Intervention & 25 & 40,79 & 9,322 & $41-60$ \\
Composite & 2. Control & 25 & 48,23 & 8,109 & $43-60$ \\
\cline { 2 - 5 } & Total & 50 & 44,51 & 2,711 & $41-60$ \\
\hline
\end{tabular}

Results of cognitive response analysis in table 3 showed that from 50 respondents, the average value of cognitive response before following CBT with flashcard media was 15,31 with a minimum value 9 and maximal value 23. It can conclude that the average value of cognitive response on the risk of violent patients before following the CBT with flashcard media was in the moderate category $($ Low $=5-10$, Moderate 11-15, High 16-20)

Results of affective response to violent behavior in risk of violent behavior patients showed that from 50 respondents, the average value of affective response before CBT with flashcard media was 18,35 and in the medium category (Low $=5-10$, Moderate $=11-15$, High 16-20) with minimum value 6 and maximal value 10 
Based on the questionnaire of behavior response to violent behavior in table 3 showed that from 50 respondents, behavior response to violent behavior before CBT with flashcard intervention was 15,16 with minimum value 7 and maximal value 20 were in the moderate category. Based on the table, social response on 50 risks of violent behavior clients was also in the moderate category. It was shown by the average value 16,57 with a minimum value 11 and a maximum value 20. Based on the questionnaire, physiological response on the risk of violent behavior clients was 5 minimum and 10 maximum (low 5-6, moderate 7-8, High 9-10). Analysis of physiological response risk of violent behavior patients showed that the average value of physiological response before CBT with flashcard was 8,44 with minimum value 7 and maximal value 10 .

Based on the table, out of 50 clients showed the average value of signs and symptoms before CBT with Flashcard media was 44,51 with a minimum value 41 and a maximum value 60. It can be concluded that the average sign and symptoms risk of violent behavior client before CBT with Flashcard were in the moderate category

Table 4. Analysis of Sign and Symptoms on Risk of Violent behavior before and after CBT with Flashcard Media in The Intervention and Control Groups at Ernaldi Bahar Hospital Palembang $(\mathbf{n}=\mathbf{5 0})$

\begin{tabular}{clccccc}
\hline $\begin{array}{c}\text { Sign and symptoms Risk } \\
\text { of Violent Behavior }\end{array}$ & Groups & $\begin{array}{c}\text { Mean } \\
\text { Before }\end{array}$ & $\begin{array}{c}\text { Mean } \\
\text { After }\end{array}$ & $\begin{array}{c}\text { Mean } \\
\text { Difference }\end{array}$ & $\begin{array}{c}\text { SD } \\
\text { Difference }\end{array}$ & $\begin{array}{c}\text { P } \\
\text { Value }\end{array}$ \\
\hline \multirow{2}{*}{ Cognitive } & 1. Intervention & 15,03 & 6,73 & 8,3 & 2,745 & 0,000 \\
& 2. Control & 15,6 & 11,26 & 4,34 & 3,014 & 0,000 \\
Affective & 1. Intervention & 18,03 & 8,73 & 9,3 & 3,122 & 0,000 \\
& 2. Control & 18,67 & 14,2 & 4,47 & 3,543 & 0,000 \\
Behavior & 1. Intervention & 14,53 & 6,73 & 7,8 & 3,087 & 0,000 \\
& 2. Control & 15,67 & 12,97 & 2,7 & 3,266 & 0,000 \\
Social & 1. Intervention & 18,27 & 6,88 & 11,39 & 3,299 & 0,000 \\
& 2. Control & 18,67 & 13,97 & 4,7 & 4,018 & 0,000 \\
Physiological & 1. Intervention & 8,27 & 5,19 & 3,08 & 1,136 & 0,000 \\
& 2. Control & 8,6 & 6,27 & 2,33 & 1,877 & 0,000 \\
\multirow{2}{*}{ Composite } & 1. Intervention & 40,79 & 21,37 & 19,42 & 8,979 & 0,000 \\
& 2. Control & 48,23 & 40,78 & 7,45 & 11,086 & 0,000 \\
\hline
\end{tabular}

Based on table 4, the analysis results in signs and symptoms of violent behavior before and after CBT with flashcard media on intervention and control groups. There were significant differences in which both groups experienced a decrease despite the different number of reductions. A greater decreased number was found in the intervention groups where before being given CBT with flashcard media, the intervention group had an average value in signs and symptoms of violent behavior 64,97 and in the moderate category. While after the intervention, the average value in 
signs and symptoms of violent behavior was decreased to 31,37 and are in a low category or decreased sign and symptom risk of violent behavior on intervention group was by $48 \%$. Meanwhile, the control group, before being given intervention, had an average value sign and symptoms of violent behavior 67,98 and in the moderate category. After the intervention, the average value of signs and symptoms of violent behavior was decreased to 56,78 and still in a moderate category or symptoms were the same as before the intervention. Decreased sign and symptom risk of violent behavior on control group were only by $15,4 \%$

Table 5. Analysis of Changes in Decreased Risk of Violence Sign and Symptoms after CBT with Flashcard Media in Intervention and Control Group at Ernaldi Bahar Hospital Palembang $(\mathbf{n}=\mathbf{5 0})$

\begin{tabular}{|c|c|c|c|c|c|c|}
\hline $\begin{array}{c}\text { Sign and } \\
\text { symptoms on } \\
\text { Risk of violent } \\
\text { behavior }\end{array}$ & Group & $\mathbf{n}$ & Mean & SD & Category & P-value \\
\hline \multirow[t]{3}{*}{ Cognitive } & 1. Intervention & 25 & 6,73 & 1,034 & Low & \multirow[t]{3}{*}{0,000} \\
\hline & 2. Control & 25 & 11,26 & 3,146 & Moderate & \\
\hline & Total & 50 & & & & \\
\hline \multirow[t]{3}{*}{ Affective } & 1. Intervention & 25 & 8,73 & 1,297 & Low & \multirow[t]{3}{*}{0,000} \\
\hline & 2. Control & 25 & 14,20 & 3,976 & Moderate & \\
\hline & Total & 50 & & & & \\
\hline \multirow[t]{3}{*}{ Behavior } & 1. Intervention & 25 & 6,73 & 1,213 & Low & \multirow[t]{3}{*}{0,000} \\
\hline & 2. Control & 25 & 2,97 & 2,987 & Moderate & \\
\hline & Total & 50 & & & & \\
\hline \multirow[t]{3}{*}{ Social } & 1. Intervention & 25 & 6,88 & 1,233 & Low & \multirow[t]{3}{*}{0,000} \\
\hline & 2. Control & 25 & 13,97 & 3,314 & Moderate & \\
\hline & Total & 50 & & & & \\
\hline \multirow[t]{3}{*}{ Physiological } & 1. Intervention & 25 & 5,19 & 0,676 & Low & \multirow[t]{3}{*}{0,000} \\
\hline & 2. Control & 25 & 6,27 & 1,154 & Moderate & \\
\hline & Total & 50 & & & & \\
\hline \multirow[t]{3}{*}{ Composite } & 1. Intervention & 25 & 21,37 & 3,324 & Low & \multirow[t]{3}{*}{0,000} \\
\hline & 2. Control & 25 & 40,78 & 11,356 & Moderate & \\
\hline & Total & 50 & & & & \\
\hline
\end{tabular}

Based on Table 5, It was found there was a significant different sign and symptoms on risk of violent behavior after being given CBT with flashcard media on the intervention and control group, or there was a greater chance of decrease in signs and symptoms in the intervention group (low symptom category) from cognitive, affective, behavior, social, physiological response and composite in risk of violent patients after received CBT with flashcard media.

Table 6. Analysis of Composite Impairment Sign and Symptom to Violent Behavior Before and After CBT with Flashcard on Intervention and Control group at Ernaldi Bahar Hospital Palembang $(\mathbf{n}=50)$

\begin{tabular}{cllcccc}
\hline Composite & \multicolumn{1}{c}{ Group } & $\begin{array}{l}\text { Mean } \\
\text { Before }\end{array}$ & $\begin{array}{c}\text { Mean } \\
\text { After }\end{array}$ & $\begin{array}{c}\text { Mean } \\
\text { Difference }\end{array}$ & $\begin{array}{c}\text { SD } \\
\text { Difference }\end{array}$ & P value \\
\hline Violent & 1. Intervention & 64,97 & 31,37 & 33,60 & 8,979 & 0,000 \\
Behavior & 2. Control & 67,98 & 56,78 & 11,20 & 11,086 & 0,000 \\
\hline
\end{tabular}


Based on table 6, the results of composite analysis sign and symptoms to the risk of violent behavior before and after CBT with flashcard media on intervention and control group, there was significant differences where both groups had a decreased sign and symptoms, but a greater decrease has found in the intervention group. Composite response to the risk of violent behavior significantly decreased by 31,37 (Low category) on intervention group and 56,78\% (moderate category) on control group with a p-value $0,000 \leq a \mathrm{a} 0,05$. The effectiveness of CBT to decrease sign and symptoms of violent behavior was $66,6 \%$

\section{Discussion}

\section{Analysis of Signs and Symptoms on Violent Behavior In The Intervention And Control Group Before Being Given CBT With Flashcards}

Based on table 3, it was found that the signs and symptoms of the risk of violent behavior response and low self-esteem in both groups were at the same level, namely moderate. These results are in accordance with the opinion of Polite Hugler, which states that the results of quasiexperimental research are said to be valid if the characteristics of the respondents are not significantly different (homogeneous). ${ }^{15}$ The results of this study, in accordance with the opinion of the American Psychiatric Association, states that the characteristics of schizophrenic clients are determined by data on age, gender, marital status, occupation, and a history of mental disorders. ${ }^{16}$ Mariestela (2016) points out that one clear disadvantage of group work for people with complex problems is that it lacks the flexibility to respond to diverse problem presentations, and they suggest that group CBT for psychosis might bemire effective if there were homogeneity of symptom experience. However, in their study, even when the group focused on the common experience of violence were not reduced, although there was some indication that participants treated by more expert therapists fared better. ${ }^{17}$

Mental nursing standard action which is given to the patient with schizophrenia has a reaction to changes in the patient's abilities to control the risk of violence and inferiority. In accordance with the research conducted by Sujarwo, it was found that the implementation of most effective strategies for implementing violent behavior was SP 1 for physical relaxation exercises and SP 3 for spiritual worship ${ }^{18}$ Another research conducted by Sutinah found that the results of the bivariate statistical test showed that there was an effect of implementing strategies for implementing low self-esteem in schizophrenia clients with a p-value of $0.01 .{ }^{19}$ Implementation strategies are one of the nursing standard mental actions. That aim to increase the client's selfesteem by discussing the client's positive abilities and practicing this positive ability. ${ }^{20}$ 


\section{Analysis of Sign And Symptoms On Risk of Violent Behavior Before And After CBT With Flashcards In The Intervention And The Control Group}

Based on table 4, there was a greater decrease in the intervention group after being given CBT with flashcard, compared to the control group, which showed a decrease by $48 \%$ from the middle category to low category, while in the control group only by $15.4 \%$ was in the unchanged category or stayed in the middle category. The implementation of CBT therapy aims to change the cognitive and behavior of schizophrenic clients, where before changing the client's behavior begins with skills to change cognitively. In the case of schizophrenia with individual violent behavior, ambiguous people are always in anxiety, have a negative assessment of themselves and other people, the inability to solve problems properly, have difficulty thinking clearly, and tend to be restless. ${ }^{21}$ A stimulus was needed to change a person's behavior. This is in accordance with Hartono's opinion that behavior is an activity that arises from stimuli and responses and can be observed directly or indirectly. ${ }^{22}$ According to Skinner, explains that behavior arises because of the relationship between stimulus and response. ${ }^{23}$ Researchers used flashcards as a stimulus or stimulant so that the expected behavior appears, so the subject can understand the concept of positive thinking through appropriate responses. Meanwhile, Chatib explained that flashcard media is a card containing pictures or writing related to the concept. ${ }^{24}$ Windura said that the flashcard or cards used to remember, review in the learning process, are very fun and can be used in the form of a game. The contents of the card on the flashcards used in the application of CBT include negative thoughts that are generally owned by schizophrenic clients and include positive thoughts to counter these negative thoughts. The principle in this CBT game with flashcards was preceded by cognitive recovery through training against negative automatic thoughts by taking cards whose contents are negative thoughts according to what clients often think and choosing cards with positive thoughts, pairing them while saying aloud and excited. The activity of seeing flashcard media, mentioning writing, hearing the sound of letters being read makes clients better at remembering and recognizing, connecting facts with concepts. ${ }^{25}$ The concept in CBT is to replace negative thoughts with positive thoughts and reinforce positive thoughts to generate strong motivation to show adaptive behavior. ${ }^{26}$ There was an alteration that very important, because good changes start from goof self-awareness so that can be maintained or sustainable behavior.

The results of the study in the control group also experienced a decrease in risk signs of violent behavior in the moderate category. It means that the generalist therapy given is quite effective. However, the control group was at risk for returning to a higher symptom of violent behavior around $80 \%$ in the future if no additional therapeutic innovation changes are given to improve the client's quality of life. For the patient coping strategies in the face of stressful events that need to be prepared either by giving Cognitive Behavior Therapy (CBT). ${ }^{27,28}$ 


\section{Analysis of Changes in Decreased Risk of Violence Sign and Symptoms After CBT with Flashcard}

Based on table 5, the results of the analysis of differences and decreases in the intervention and control groups show that there is a statistically significant difference where the difference in the decrease in signs and symptoms in the intervention group is low, and the control group is still in the moderate category. CBT therapy can help create a positive and realistic attitude for negative cognitive and emotional attitudes. ${ }^{29}$ The process of learning or thinking that occurs in the memory system of the human brain produces a model of information processing in the learning process (theory learning). When an individual receives certain information or stimulus, it will be detected by sensory systems in the brain. It will create a learning process for an individual, and the results of processing are stored in memory in the form of knowledge that will be used later in a real event. This sensory system is composed of receptors and connecting neurons from the five senses (hear, see, smell, taste, and feel), and the area that processes visual information is the occipital lobe and is actively connected to the prefrontal cortex as the center of rational thinking. ${ }^{11}$

The tool serves to facilitate the continuity of the learning process based on the principle that the knowledge possessed by every human being is received or captured through the senses, where someone can remember $50 \%$ of what was seen and heard. The result is consistent with Dale's learning experience, which stated that in learning, humans use $75 \%$ visual and $13 \%$ audio sensory, so the more senses are used to receive information, the more clear the knowledge obtained. ${ }^{30}$ Based on the study conducted by Pipitcahyani and Safitri, the results showed a significant difference between the flipchart groups and the flashcard group, an increase in knowledge in the intervention group reached $90 \%$, and in the control group was only $30 \%$ in mothers who had a good level of knowledge. ${ }^{31}$ At present, we did not find any theories or other studies that conflicted with the effectiveness and the use of flashcard learning media. As Mason said, learning media is a tool that can be manipulated and used to affect students' minds, feeling, attention and attitude. Flashcards can help the learning process easier. ${ }^{32}$ A similar study that supports that opinion suggested that balancing the functions of the left brain and the right brain with flashcard media is quite sufficient to boost the ability of children, this even considered as one of the right stimuli in the child's brain to be given as early as possible. ${ }^{33}$ The CBT model was also developed to improve the degree of mental health for mental health problems, one of which is controlling anger in schizophrenic clients. $^{34}$

The CBT using flashcard media was carried out using a group approach. Giving CBT that was done by playing in groups was a better alternative than individual CBT in early-stage psychosis client ${ }^{\mathrm{s} .17}$ CBT therapy was carried out in 5 sessions which include session 1: problem assessment and formulation, session 2: cognitive therapy, session 3: behavioral therapy, session 4:evaluation, and session 5: relapse prevention. The use of flashcards was in sessions 1-3. Whereas 
sessions 4 and 5 are activities to change cognitive and behavioral distortions in CBT in the form of carrying out independent work tasks so that patients have the opportunity to internalize what they learn in groups. ${ }^{15}$

In order to strengthen the expected behavior to remain, the researchers provides reinforcement positive at each session. Socials reinforcement for the emergence of the expected behavior: namely about the operant response (instrumental response) responses that arise and develop followed by certain stimuli. ${ }^{23}$ Rewarding is also done to reinforce desired behavior or eliminate unwanted behavior. ${ }^{35}$

The results of this study indicated that there was a decrease of more than $50 \%$ in the cognitive, emotional, physiological, social, and behavioral responses of respondents with risk problems for violent behavior. This is because the patient has the ability to think positively and can distinguish between rational and irrational thoughts. Based on the results of research on CBT using flashcard that has been implemented, it was found that several respondents expressed negative thoughts according to the cards they got. Mr. L received a negative thought card that "I am always blamed" which was also owned by 3 other respondents. According to Mr. L, he always felt blamed, especially in terms of work by his boss. Mr. L said that his boss was often angry because he thought Mr. L was not doing a good job. To get rid of these negative thoughts, Mr. L took a card containing positive thoughts that "this thought is wrong, I will recover, and I am useful". In accordance with the 4th CBT session, the nurse motivated Mr. L to adopt a positive behavior by carrying out the task of distributing snacks and lunch to other patients. After going through session 5 for 1 week, the observation results showed that the signs of the respondent's violent behavior decreased and decreased. This study was in line with Retty's research, where there was an $85 \%$ decrease in signs of violent behavior after being given cognitive behavior therapy and assertive training. ${ }^{36}$

\section{Analysis of Composite Impairment of Violent Behavior Sign and Symptoms Before and After CBT with Flashcards in the Intervention and Control Groups}

Based on table 6 , the results showed a significant change in the signs of risk symptoms for violent behavior after receiving cognitive behavior therapy with flashcards compared to patients who did not receive cognitive behavior therapy with a p-value of 0.000 . This is because cognitive behavior therapy is a form of psychotherapy that can improve the cognitive abilities and behavior of schizophrenic patients with low self-esteem and risk of violent behavior in overcoming the problem. The results also show an average decrease in response to violent behavior (cognitive, emotional, behavioral, etc., physiological and social) in the intervention group is greater than the control group. This is a factor in the existence of cognitive behavior therapy, which acts more on the core problem of the patient, about his belief in the situation, environment, other people, and the 
environment, which is interpreted incorrectly through cognitive processes and ultimately manifested in the form of behavior (output).

The results of this study are in line with Satrio's research where the effectiveness of CBT by $61 \%$ was able to reduce symptoms of violent behavior. ${ }^{37}$ Based on this study, the cognitive, affective, and behavioral responses of schizophrenia patients can be changed to positive ones if cognitive behavior therapy is given even though in the process, the patient is still receiving antipsychotic therapy. This opinion is supported by Turkington, which shows satisfactory results where pharmacotherapy combined with problem-oriented and task-oriented therapy can change cognitive errors or biases by assessing situations and modifying new adaptive behaviors. ${ }^{38}$ In this study, respondents were assisted in orientating toward the initial flashcards which contain negative thoughts that often arise and interfere with their thoughts, then the respondent tells his thoughts, then the respondent takes another flashcard containing 4 kinds of positive thoughts that are exactly what they want to be paired with the first flashcard. Respondents who found and paired the cards the most and carried out the behavior in accordance with their positive thoughts, the respondent had the right to get reinforcement. The therapy of playing CBT with flashcards which were carried out in groups and scheduled three times a week in this study, has proven its effectiveness in reducing the response of signs and symptoms of risk of violent behavior.

According to my assumption, CBT research using flashcard media has many advantages, including CBT flashcard games were fun, easy to do without the need for a therapist, not boring, has been effective, faster in generating positive thoughts, calm feelings, preventing angry behavior. In addition, the CBT flashcard game can be played in small or large groups, which the game had been increased the confidence and happiness of the players because, in the game, there was praise, appreciation for each player. While the drawback of this research was that players had lost track of time because they were too busy and enjoyed playing CBT flashcards. The limitations of this CBT flashcard game cannot be done by players who cannot read the writing on the card

\section{Conclusion}

However, after being given CBT treatment with flashcards in the intervention group, the respondents experienced a decrease in signs and symptoms of the risk of violent behavior by $48 \%$ so that finally, the respondents were in the low category stage while in the control group, there was no change where respondents were still at the same level. that is, the moderate level has the risk of committing violent behavior. Thus, the application of the flashcard method on CBT in groups is very effective in reducing the signs and symptoms of the risk of committing violent behavior within an effectiveness value of $66.6 \%$. So far, the use of flashcard CBT games has been successful more quickly and effectively in preventing the risk of violent behavior during hospitalization compared to patients who did not receive the intervention. 


\section{Acknowledgment}

We would like to express our gratitude to the Division of Ernaldi Bahar Hospital for the facilities and cooperation. Equally, we are grateful to all contributing parties, especially all nurses, lectures, and the research team.

\section{Funding}

There is no funding for this research, and the funds used are the author's personal funds.

\section{Conflict of Interest}

There is no conflict of interest in this study

\section{References:}

1. Dijk KH and L Van. The world medicines situation: rational use of medicines. World Med Situat. 2011;2(2):24-30.

2. Idaiani S, Yunita I, Tjandrarini DH, Indrawati L, Darmayanti I, Kusumawardani N, et al. Prevalensi Psikosis di Indonesia berdasarkan Riset Kesehatan Dasar 2018. J Penelit dan Pengemb Pelayanan Kesehat. 2019;3(1):9-16.

3. Palembang K. Laporan Akuntabilitas Kinerja Instansi Pemerintah ( Lakip ) Rumah Sakit Ernaldi Bahar Provinsi Sumatera Selatan Tahun 2016. 2016;(02):5645126.

4. Stolzer JM. The meteoric rise of mental illness in America and implications for other countries. Eur J Couns Psychol. 2016;4(2):228-46.

5. Kemenkes RI. Hasil Riset Kesehatan Dasar Tahun 2018. Kementrian Kesehat RI. 2018;53(9):1689-99.

6. Stuart Laraia.

7. Bademli K, Duman ZÇ. Effects of a Family-to-Family Support Program on the Mental Health and Coping Strategies of Caregivers of Adults With Mental Illness: A Randomized Controlled Study. Arch Psychiatr Nurs. 2014;28(6):392-8.

8. WHO. World HealtH Statistics. World Heal Stat. 2012;5-6.

9. Prakosa PWB. Dimensi Sosial Disabilitas Mental di Komunitas Semin, Yogyakarta. Sebuah Pendekatan Representasi Sosial. J Psikol [Internet]. 2015;32(2):61-73. Available from: https://journal.ugm.ac.id/jpsi/article/view/7071

10. Gillespie K, Duffy M, Hackmann A, Clark DM. Community based cognitive therapy in the treatment of post-traumatic stress disorder following the Omagh bomb. Behav Res Ther. 2012;40(4):345-57.

11. Talakar M, Haghayegh SA, Mirzaian B. The effect of cognitive-behavioral group therapy 
on anger and general health of female students in Iran: A pilot study. Iran J Psychiatry Behav Sci. 2016;10(4):0-5.

12. Suerni T, Keliat BA, C.D NH. Penerapan Terapi Kognotif Dan Psikoedukasi Keluarga Pada Klien Harga Diri Rendah Di Ruang Yudistira Rumah Sakit Dr. H. Marzoeki Mahdi Bogor Tahun 2013. J Keperawatan Jiwa. 2013;161-9.

13. Sri M, Nurna N. Pengaruh Cognitive Behaviour Therapy (CBT) Terhadap Perubahan Harga Diri Pasien Perilaku Kekerasan Dengan Aplikasi Model Token Economy. Semin Nas Keperawatan "Tren Perawatan Paliat sebagai Peluang Prakt Keperawatan Mandiri." $2018 ; 194-8$.

14. Tim SDKI DPP PPNI. Risiko Perilaku Kekerasan Pada Pasien Skizofrenia. J Keperawatan Dan Kesehat Masy Cendekia Utama. 2017;2(4):4149.

15. Kopelovich SL, Strachan E, Sivec H, Kreider V. Stepped Care as an Implementation and Service Delivery Model for Cognitive Behavioral Therapy for Psychosis. Community Ment Health J [Internet]. 2019;55(5):755-67. Available from: http://dx.doi.org/10.1007/s10597018-00365-6

16. L.Videbeck S. Psychiatric-Mental Health Nursing. Vol. 148. 148-162 p.

17. Candida M, Campos C, Monteiro B, Rocha NBF, Paes F, Nardi AE, et al. Cognitivebehavioral therapy for schizophrenia: an overview on efficacy, recent trends and neurobiological findings. Med Express. 2016;3(5):1-10.

18. Sujarwo S, PH L. Studi Fenomenologi: Strategi Pelaksanaan Yang Efektif Untuk Mengontrol Perilaku Kekerasan Menurut Pasien Di Ruang Rawat Inap Laki Laki. J Keperawatan Jiwa. 2019;6(1):29.

19. Sutinah. PENGARUH PENERAPAN STRATEGI PELAKSANAAN HARGA DIRI RENDAH TERHADAP HARGA DIRI KLIEN SKIZOFRENIA.

20. Keliat BA. Kontribusi Keperawatan Kesehatan Jiwa Dalam Meningkatkan Pelayanan Kesehatan Jiwa di Indonesia. 2015;

21. Cho WK, Shin WS, An I, Bang M, Cho DY, Lee SH. Biological aspects of aggression and violence in Schizophrenia. Clin Psychopharmacol Neurosci. 2019;17(4):475-86.

22. Emzir. Pemikiran Islam di Malaysia Sejarah dan Aliran. 2017;7(1):37-8.

23. Ismainar. Daftar Pustaka. Ekp. 2015;13(3):1576-80.

24. Salma A. Konsep Guru Profesional dalam Buku Gurunya Manusia karya Munif Chatib dan Urgensinya terhadap Kompetensi Guru Kelas Madrasah Ibtidaiyah. 2021;(April):1-76.

25. Hotimah E. Penggunaan Media Flashcard dalam Meningkatkan Kemampuan Siswa pada Pembelajaran Kosakata Bahasa Inggris Kelas II MI Ar-Rochman Samarang Garut. J Pendidik Univ Garut [Internet]. 2010;4(1):10-8. Available from: www.journal.uniga.ac.id

26. Gregory VL. Cognitive-behavioral therapy for schizophrenia: Applications to social work 
practice. Soc Work Ment Health. 2012;8(2):140-59.

27. Beck JG, Coffey SF. Group cognitive behavioral treatment for PTSD: Treatment of motor vehicle accident survivors. Cogn Behav Pract. 2015;12(3):267-77.

28. Zafar AM, Jawaid A, Ashraf H, Fatima A, Anjum R, Qureshi SU. Psychotherapy as a treatment modality for psychiatric disorders: Perceptions of general public of Karachi, Pakistan. BMC Psychiatry. 2011;9:1-5.

29. Høifødt RS, Strøm C, Kolstrup N, Eisemann M, Waterloo K. Effectiveness of cognitive behavioural therapy in primary health care: A review. Fam Pract. 2011;28(5):489-504.

30. Masters K. Edgar Dale's Pyramid of Learning in medical education: A literature review. Med Teach. 2013;35(11):1584-93.

31. Ninla Elmawati Falabiba. Global Medical and Health Communication. 2019.

32. Muhson A. Pengembangan Media Pembelajaran Berbasis Teknologi Informasi. J Pendidik Akunt Indones. 2013;8(2).

33. Baska DY, Madjid TH, Idjradinata PS. The Effect of Health Education with Flashcard Media on Improvement of Knowledge and Reduction of Anxiety Degree in Adolescents Primigravida. Glob Med Heal Commun. 2020;8(1):59-66.

34. Adina JO, Maritim EK, Sindabi AM, Disiye MA. Effect of cognitive behaviour therapy on depressive symptoms among HIV-infected outpatients in Kenya. Int J Psychol Psychol Ther. 2017;17(2):161-73.

35. Wakhid A, Yani A, Hamid S, Cd H, Akper ), Waluyo N. Penerapan Terapi Latihan Ketrampilan Sosial Pada Klien Isolasi Sosial Dan Harga Diri Rendah Dengan Pendekatan Model Hubungan Interpersonal Peplau Di Rs Dr Marzoeki Mahdi Bogor. Mei. 2013;1(1):34-48.

36. Widianti E, Keliat BA, Wardhani IY. Aplikasi Terapi Spesialis Keperawatan Jiwa Pada Pasien Skizofrenia Dengan Harga Diri Rendah Kronis Di Rsmm Jawa Barat. J Pendidik Keperawatan Indones. 2017;3(1):83.

37. Lelono S.Terapi D, Dan M, Emotive R, Behavior C. Prevalensi Skizofrenia cukup tinggi dan terjadi pada usia produktif . 2012;

38. Turkington D, Kingdon D, Weiden PJ. Cognitive behavior therapy for schizophrenia. Am J Psychiatry. 2013;163(3):365-73. 